Int. J. Morphol.,

33(2):600-606, 2015.

\title{
Anthropometry of the Black Adult Tibia: A South African Study
}

\author{
Antropometría de la Tibia del Negro Adulto: Un Estudio Sudafricano
}

\author{
N. Naidoo"; L. Lazarus"; N. O. Ajayi* \& K. S. Satyapal"
}

\begin{abstract}
NAIDOO, N.; LAZARUS, L.; AJAYI, N. O. \& SATYAPAL, K. S. Anthropometry of the Black Adult tibia: A South African study. Int. J. Morphol., 33(2):600-606, 2015.

SUMMARY: The tibia is the medial long bone of the leg and is characterized by a shaft and two expanded extremities. Despite the recent advent of tibial bone graft harvesting, the tibia has also been confirmed to be of great forensic significance. As this appears to be the only tibial dry bone study done in Southern Africa, this study aimed to investigate morphological and morphometric parameters that are of clinical and anthropometric importance. Morphological and morphometric examination of 302 adult tibial bone specimens of Black South Africans obtained from the osteological bank of the Discipline of Clinical Anatomy at the University of KwaZulu-Natal was performed. The sample consisted of 168 males and 134 females with an age range of 15 to 87 years old. The number of nutrient foramina were: (a) One (male: $98.2 \%$; female: 99.3\%); (b) Double (male: 1.8\%; female: 0.7\%); Relationship of nutrient foramen to the soleal line: (a) infero-medial (male: $0.6 \%$; female: $1.5 \%$ ); (b) inferior but directly opposite the middle of the bone (male: $8.2 \%$; female: $2.2 \%$ ); (c) infero-lateral (male: $81.8 \%$; female: $88.9 \%$ ); (d) infero-lateral, along interrosseous crest (male: $4.1 \%$; female: $3.0 \%$ ); (e) supero-medial (male: $4.7 \%$; female: $3.7 \%$ ); (f) supero-medial, along interrosseous crest (male: $0.6 \%$; female: 0\%); (g) supero-lateral (male: $0 \%$; female: $0.7 \%$ ). Statistically significant differences were recorded in tibial morphometric parameters between males and females. The relationship between the number of nutrient foramina and the soleal line was of statistical significance $(\mathrm{p}=0.002)$. The greater prevalence of a single foramen observed in this study compared favorably with that reported in previous literature. The recognition of the regional distribution of the nutrient foramina may prevent injury during tibial bone graft procedures. A thorough understanding of the tibial anatomy may also assist with the provision of demographic data required in forensic investigation.
\end{abstract}

KEY WORDS: Tibia; Nutrient Foramen; Soleal Line; Morphometry.

\section{INTRODUCTION}

The tibia, popularly known as the shinbone, is situated in the antero-medial aspect of the leg parallel to the medial side of the fibula (Moore et al., 2010). It is the second largest bone in the body, with its length exceeded by that of the femur (Standring, 2008; Moore et al.). Although, it is comparatively vertical along its length, the proximal and distal ends extend outwardly (Moore et al.). The tibia classically presents with three distinctive parts, viz. proximal and distal ends and a shaft (Standring; Moore et al.). The nutrient foramen, which is situated obliquely at the superior end of the vertical line on the posterior surface, provides entry into the medullary cavity (Shapiro, 2008; Moore et al.; Kulkarni, 2012).

Standring stated that morphologic and morphometric differences of the tibia may be related to racial and individual variations. Iscan \& Miller-Shaivitz (1984) reported that sexual dimorphism was greater in Black individuals than in Caucasians and thus dependent on race. In the Japanese study conducted by Iscan et al. (1994), females appeared to have longer tibia than males. It was suggested that the determination of sex may require consideration of the demographic factor of the population in question.

The recent identification of the nutrient foramen on the proximal tibia as the ideal harvest site for the surgical reconstruction and restoration of chronic and acute pathological defects in the head and neck region, has accounted for the global incidence of approximately one million bone graft procedures annually (Greenwald et al., 2001; Benninger et al., 2012). According to Longia et al. (1980), classically the tibia usually has a single nutrient foramen in comparison with the number of nutrient foramina in other long bones. In the studies conducted by Mysorekar 
(1967) and Bokariya et al. (2012), single and double nutrient foramina were found on the posterior tibial surface. Due to the usual presence of a single nutrient foramen, in circumstances of increased stress or decreased bone rigidity, the resultant longitudinal fracture and associated medullary edema has been linked to unsatisfactory outcome (Craig $e t$ al., 2003; Shapiro; Arora et al., 2012).

Since many studies focus only on the procedural and epidemiological aspects of the tibia, there is paucity of literature regarding the tibial anatomy (Benninger et al.). A comprehensive review of the literature confirmed that the present study is exclusive to Southern Africa. As the majority of studies pertaining to the tibia employ various types of imaging resources as opposed to dry bone specimens (Benninger et al.; Musa et al., 2013), the present study aimed to investigate the morphologic and morphometric parameters of the dry tibial osteology.

\section{MATERIAL AND METHOD}

The examination of 302 randomly selected, unpaired adult dry tibial bones obtained from the osteological bank at the Discipline of Clinical Anatomy, School of Laboratory Medicine and Medical Sciences at the University of KwaZulu-Natal was performed. Ethical clearance was obtained from the relevant institutional Ethics committee (Ethics number: BE409/13).

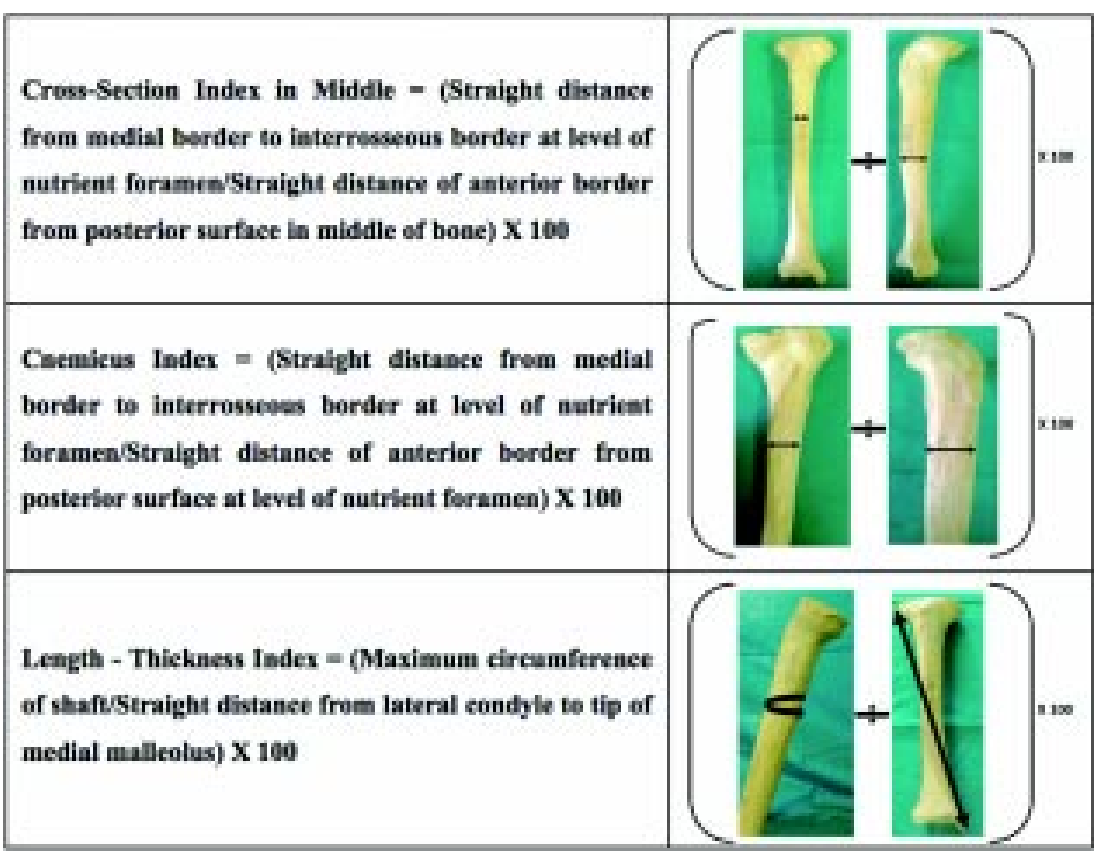

Fig. 1. Indexical Formulae as stated by Bokariya et al. (2012). * Cnemicus index is a morphometric parameter referring specifically to the presence of the nutrient foramen
The sample series was entirely from the Black population group of KwaZulu-Natal, South Africa. In addition, the sample consisted of 168 males and 134 females with an age range of 15 to 87 years old (Table I). Tibiae with fragmented condyles, malleoli and intercondylar tubercles or those that displayed evidence of previous fracture were excluded. All measurements were done with the aid of a digital caliper (Mitutoyo Digimatic Caliper, Model No. CD8 " C). The standard indexical formulae as stated by Bokariya et al.) were adopted and determined (Fig. 1).

Table I. Demographic representation of the sample series $(n=302)$.

\begin{tabular}{ccccc}
\hline \multirow{2}{*}{ Demographic Factor } & \multicolumn{2}{c}{ Sex } & \multicolumn{2}{c}{ Side } \\
\cline { 2 - 5 } & Male & Female & Right & Left \\
\hline & 168 & 134 & 138 & 164 \\
\hline
\end{tabular}

Tibial parameters between both sexes were compared and correlated. The statistical analysis was performed using the Statistical Package for Social Sciences version 21.0 (SPSS Inc., Chicago, Illinois, USA). A p value of $<0.05$ was considered to be statistically significant.

\section{RESULTS}

Morphology. The incidences of the respective tibial morphological parameters were documented: (i) Nutrient foramina: (a) Single (male: 98.2\%; female: $99.3 \%$ ); (b) Double (male: $1.8 \%$; female: $0.7 \%$ ) (Fig. 2; Table II); (ii) Shape of tibial tuberosity: Inverted-U (male: 100\%; female: $100 \%$ ) (Table III); (iii) Relation of nutrient foramen to soleal line: (a) infero-medial (male: $0.6 \%$; female: $1.5 \%$ ); (b) inferior but directly opposite middle of the bone (male: $8.2 \%$; female: $2.2 \%$ ); (c) infero-lateral (male: $81.8 \%$; female: $88.9 \%$ ); (d) infero-lateral, along interrosseous crest (male: $4.1 \%$; female: $3.0 \%$ ); (e) supero-medial (male: $4.7 \%$; female: $3.7 \%$ ); (f) supero-medial, along interrosseous crest (male: $0.6 \%$; female: $0 \%)$; $(\mathrm{g})$ supero-lateral (male: 0\%; female: $0.7 \%$ ) (Fig. 3; Table II). In addition, the comparison of the number of nutrient foramina with their relationship to the soleal line yielded a p value of 0.002 (Table II). 
NAIDOO, N.; LAZARUS, L.; AJAYI, N. O. \& SATYAPAL, K. S. Anthropometry of the Black Adult tibia: A South African study. Int. J. Morphol., 33(2):600-606, 2015.

Table II. Incidence of morphological parameters and P values.

\begin{tabular}{llcc}
\hline \multirow{2}{*}{ Morphological Parameter (\%) } & \multicolumn{2}{c}{ Sex } \\
\cline { 2 - 4 } Number of nutrient foramina & Single & Male & Female \\
\cline { 2 - 4 } P Value & Double & 98.2 & 99.3 \\
Shape of tibial tuberosity & Inverted U & 1.8 & 0.7 \\
P Value & & \multicolumn{2}{c}{0.429} \\
Relationship of nutrient foramen & 100 & 100 \\
to soleal line & Infero-medial & \multicolumn{2}{c}{ Constant } \\
& Inferior but directly opposite middle of bone & 0.6 & 1.5 \\
& Infero-lateral & 8.2 & 2.2 \\
& Supero-medial along interrosseous crest & 4.8 & 88.9 \\
& Supero-medial, along interrosseous crest & 4.7 & 3.7 \\
P Value & Supero-lateral & 0.6 & 0 \\
& & 0 & 0.7
\end{tabular}

Relationship between the number of nutrient foramina and their location to the soleal line

P Value

0.002

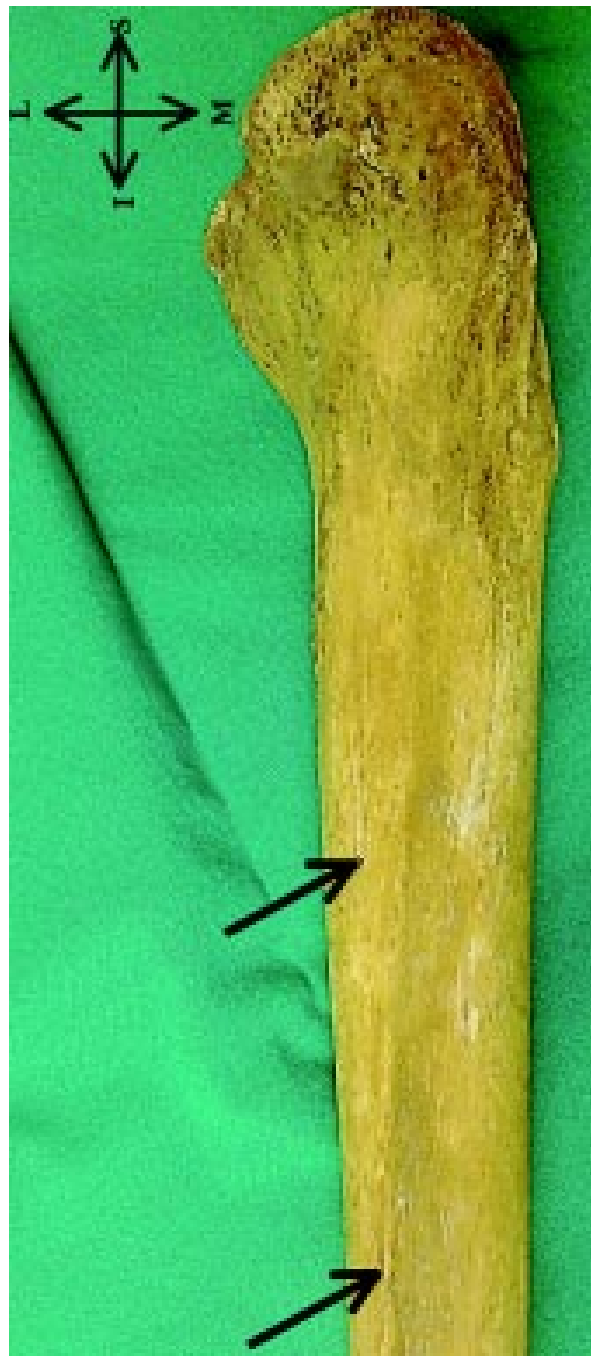

Fig. 2. Posterior view showing the presence of double tibial foramina. Key: I= Inferior; $\mathrm{L}=$ Lateral; $\mathrm{M}=$ Medial; $\mathrm{S}=$ Superior.

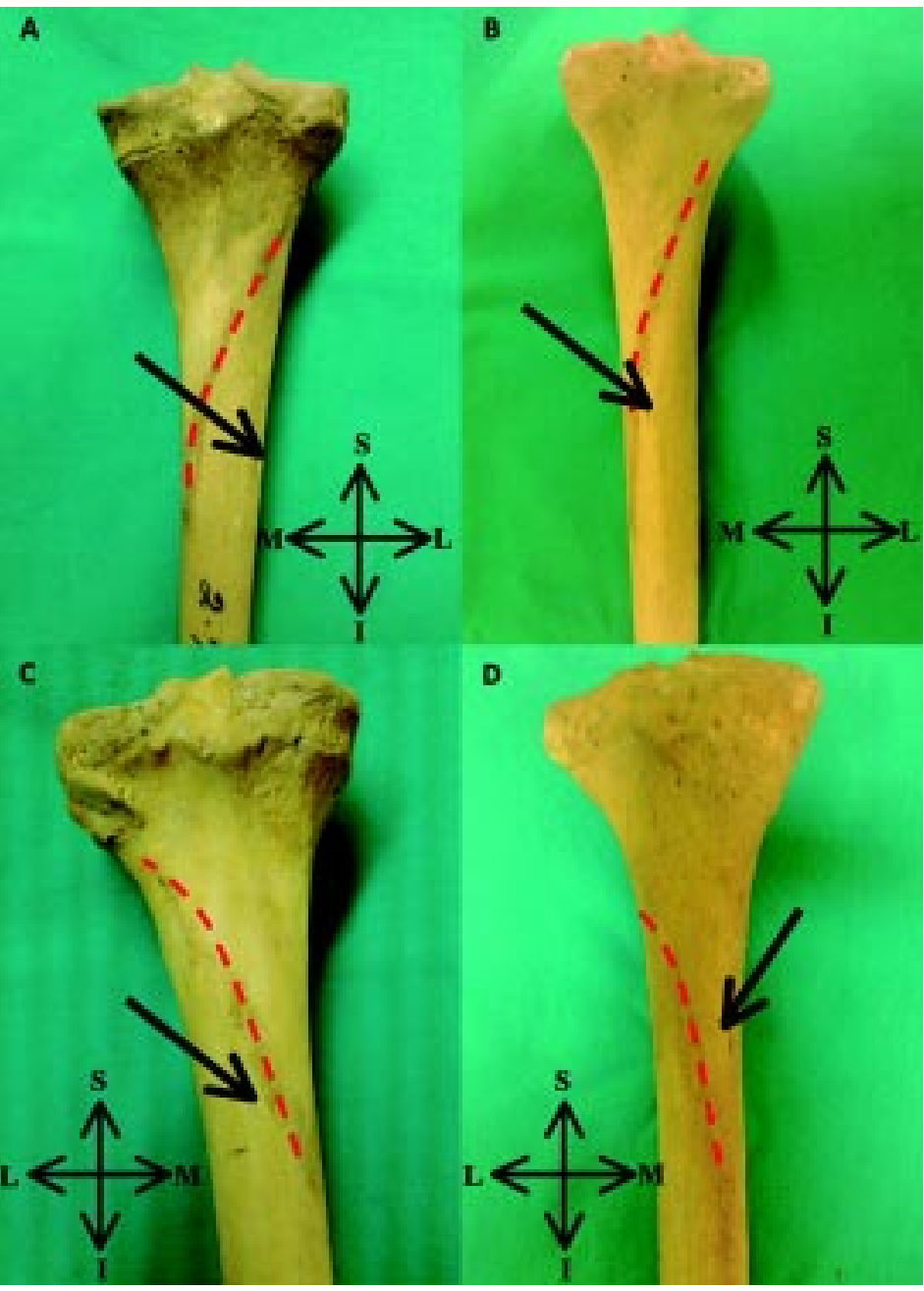

Fig. 3. Posterior view of relation of tibial nutrient foramen to soleal line: $A=$ Infero-lateral along interrosseous crest; $\mathrm{B}=$ Infero-medial; $\mathrm{C}=$ Inferior directly opposite middle of bone; $\mathrm{D}=$ Supero-medial. Key: I= Inferior; L= Lateral; M= Medial; $\mathrm{S}=$ Superior; Black arrow $=$ Nutrient foramen Red dotted line $=$ Soleal line . 
Morphometry. The mean distance between the following tibial morphometric parameters: (i) Intercondylar tubercles (male: $12.66 \mathrm{~mm}$; female: $11.23 \mathrm{~mm}$ ); (ii) Medial and lateral condyles (male: $73.47 \mathrm{~mm}$; female: $66.53 \mathrm{~mm}$ ); (iii) Inferior articular surface and tip of medial malleolus (male: $15.05 \mathrm{~mm}$; female: $14.00 \mathrm{~mm}$ ); (iv) Medial border and interrosseous crest (male: $26.18 \mathrm{~mm}$; female: $22.91 \mathrm{~mm}$ ); (v) Anterior border and posterior surface at middle of bone (male: $30.68 \mathrm{~mm}$; female: $27.95 \mathrm{~mm}$ ); (vi) Anterior border and posterior surface at level of nutrient foramen (male: $34.03 \mathrm{~mm}$; female: $30.58 \mathrm{~mm}$ ); (vii) Lateral condyle and tip of medial malleolus (male: $382.51 \mathrm{~mm}$; female: 367.09 $\mathrm{mm}$ ); (viii) Interrosseous crest and point where soleal line ends (male: $24.31 \mathrm{~mm}$; female: $21.76 \mathrm{~mm}$ ) (Table III). The maximum circumference of the tibial shaft was also recorded (male: $110.41 \mathrm{~mm}$; female: $102.75 \mathrm{~mm}$ ) (Table III).
Statistically significant differences were found between males and females in the following tibial morphometric parameters: i) Distance between intercondylar tubercles; ii) distance between medial and lateral condyles; iii) distance between inferior articular surface and tip of medial malleolus; iv) distance between medial border and interrosseous crest; v) distance between anterior border and posterior surface at middle of bone; vi) distance between anterior border and posterior surface at level of nutrient foramen; vii) distance between interrosseous crest and point where soleal line ends; viii) maximum circumference of shaft (Table III).

Indices. The mean indexical values were calculated for sex: (i) Cross-section index in middle of bone (male: 85.33; female: 81.98); (ii) Cnemicus index (male: 76.93; female: 74.92); (iii) Length-thickness index (male: 28.86; female: 27.99) (Table IV).

Table III. Mean morphometric parameters and $\mathrm{P}$ values.

\begin{tabular}{lcc}
\hline Mean Morphome tric Parameter (mm) & \multicolumn{2}{c}{ Sex } \\
\cline { 2 - 2 } Intercondylar tubercles & Male & Female \\
P Value & 12.66 & 11.23 \\
Medial \& lateral condyles & 0.000 \\
P Value & 73.47 & 66.53 \\
Inferior articular surface \& tip of medial malleolus & 0.000 \\
P Value & 15.05 & 14.00 \\
Medial border \& interrosseous crest & 0.000 \\
P Value & 26.18 & 22.91 \\
Anterior border \& posterior surf ace at middle of bone & 0.000 \\
P Value & 30.68 & 27.95 \\
Anterior border \& posterior surf ace at level of nutrient foramen & 0.000 \\
P Value & 34.03 & 30.58 \\
Lateral condyle \& medial malleolus & 0.000 \\
P Value & 382.51 & 367.09 \\
Point where soleal line ends \& interrosseous crest & 0.394 \\
P Value & 24.31 & 21.76 \\
Maximum circumference & 0.000 \\
P Value & 110.41 & 102.75 \\
\hline
\end{tabular}

Table IV. Indexical formulae.

\begin{tabular}{|c|c|c|}
\hline \multirow{2}{*}{ Formu lae } & \multicolumn{2}{|c|}{ Sex } \\
\hline & Male & Female \\
\hline Cross-Section Index in Middle & 85.33 & 81.98 \\
\hline P Value & \multicolumn{2}{|c|}{0.521} \\
\hline Cnemicus Index & 76.93 & 74.92 \\
\hline Length - Thickness Index & 28.86 & 27.99 \\
\hline P Value & \multicolumn{2}{|c|}{0.197} \\
\hline
\end{tabular}

\section{DISCUSSION}

Despite its resistance to disintegration and the ability to maintain its anatomical form posthumously, tibial fractu- res pose major challenges to suffering patients and healthcare organizations with regard to assessment and treatment (Kirici 
\& Ozan, 1999; Antonova et al., 2013; Parekh et al., 2014). Although Cristofolini et al. (2013) reported that the tibia is relatively uniform in instances of stress-force exertion; Wolff's Law states that "Every change in the form and the function of a bone or of its function alone is followed by certain definitive changes in its internal architecture". Consequently, in the observational study conducted by Newsham-West et al. (2014) it was deduced that the strength of bone is indeed related to its morphology and morphometry. While there is much emphasis and need for the application of bone architecture in the medico-legal industry, the fascination of the demographic and phenotypic factors particular to the tibia were considered to be signs of social status and beauty in the ancient civilizations of the Egyptian, Greek and Chinese dynasties (Golding, 1994; Akhlaghi et al., 2011).

Morphology. In the present study, a single nutrient foramen was more prevalent in females (99.3\%), while double nutrient foramina was recorded to be predominant in males $(1.8 \%)$ which may indicate a degree of sexual dimorphism in the Black population group that is native to South Africa.

The location of the nutrient foramina in relation to the soleal line was found to be predominantly infero-lateral (male: $81.8 \%$; female: $88.9 \%$ ). The nutrient foramina were also found to be infero-medial (male: $0.6 \%$; female: $1.5 \%$ ), inferior but directly opposite the middle of the bone (male: 8.2\% ; female: $2.2 \%$ ) and infero-lateral along the interrosseous crest (male: $4.1 \%$; female: $3.0 \%$ ). These observations were also similar to that of Mysorekar who reported the location of the nutrient foramen as infero-medial, inferior but directly opposite the middle of the bone and infero-lateral along the interrosseous crest. In addition, the present study found the nutrient foramina supero-medial, supero-medial along interrosseous crest and supero-lateral to the soleal line. These findings were not reported in the previous literature and are unique to this study. Furthermore, there was a statistically significant relationship between the number of nutrient foramina and their location to the soleal line $(p=0.002)$. This was not reported in previous studies. Although the difference in foramen number may be attributed to nutritional, genetic and growth factors; it may ultimately affect the development of the tibial bone as the nutrient arteries which traverse these foramina form a central component of the medullary circulation that is responsible for the arterial supply to the bone marrow and two-thirds of the innermost cortical layer (Shapiro; Bokariya et al.). However, the natural morphological occurrence of tibial torsion, which commences during fetal development and continues until pubertal maturation of the osteological framework, may account for the change in the classical location of the nutrient foramen in relation to the soleal line
(Gandhi et al., 2014). Despite the postulation that the degree and outcome of tibial torsion may be related to racial differences, appropriate anatomical mapping of the possible locations of the nutrient foramen in relation to the soleal line may lead to the prevention of vascular damage during surgery thus stimulating tissue-healing (Arora et al.; Gandhi et al.).

The resemblance of the tibial tuberosity to that of an inverted-U, seen in $100 \%$ of dry tibiae in the current study, may serve as the standard around which fracture patterns of avulsion injuries of the tuberosity may be accurately evaluated (Chitkara et al., 2013).

Morphometry. Morphometric tibial parameters are considered to of medico-legal importance due to the provision of stature-group-specific formulae for the determination of "personal identity" in circumstances of unknown and unclaimed human remains (Pelin \& Duyar, 2003; Akhlaghi et al.; Bokariya et al.). In the present study all mean morphometric tibial parameters were higher in males than females (Table III). Although resorption of the endosteum advances in the later stages of life for both males and females, the simultaneous process of growth and bone apposition that is specific to males only, may explain the increased tibial morphometry in males (Ruff \& Hayes, 1995).

With the exception of the tibial length, statistically significant differences were recorded for all morphometric tibial parameters between males and females (Table IV). In light of these findings, the Croatian study conducted by Slaus et al. (2013) ascertained the greater reliability of the tibial breadth dimensions as opposed to tibial length in the determination of sex. On the contrary, Agnihotri et al. (2009) recommended the combined use of tibial and ulnar lengths for the precise modeling of stature. Subsequently, the levels of significant difference computed in the current study were in accordance with Iscan \& Miller-Shaivitz who postulated that sexual dimorphism was dependent on race. Furthermore, the morphometric parameters of the proximal and distal aspects of the tibia have been reported to be invaluable in the distinction of sex (Kirici \& Ozan).

Indices. The Cross-section index in the middle of the bone, the Cnemicus index and the Length-thickness index presented with greater mean values in males (Table IV). However, the indexical values of this study cannot be compared to any other study as it was not reported in the literature reviewed. Therefore, for the purpose of comparison, further studies reporting on other race groups may be required. In addition, clinical studies may also be necessary in order to evaluate the exact hypothesis regarding tibial indices. 
In view of the extensive tibial bone anatomy, there is much reference to the role of embryological development to tibial morphology and morphometry (Shapiro). As a characteristic long bone, the tibia is derived from the mesenchymal tissue of limb buds and ossifies via endochondral bone formation during weeks 7 and 12 of fetal development (Shapiro; Lee et al., 2013). The structural stages in the formation of the tibial diaphyseal and epiphyseal regions are characterized by the presence and apposition of the primary and secondary ossification centers, respectively (Shapiro). As a result, the natural course of ontogenesis has been identified as the rate-enhancing factor of bone morphology and morphometry specific to the individual in terms of genotype, occupational habits and metabolic changes (Golding; Gosman et al., 2013).

CONCLUSION. Since the vascular supply to the tibia is a central factor in ensuring the success of orthopaedic procedures in the proximal tibial region; the understanding of the regional distribution of nutrient foramina may provide important surgical landmarks necessary to avoid injury to such regions during surgery which could result in delayed healing.

The osteological characteristics and mean morphometric tibial parameters may be considered to be important determinants of sex, race and identity for forensic investigation.

The data obtained in this study showed significant differences between males and females, thus, suggesting that the detailed understanding of the tibial anatomy may lead to the development of enhanced operative strategies and their outcome. As a result of populational variability and environmental adaptation, it may also be necessary for anatomists and skeletal biologists to provide populationspecific data which may prove to be beneficial during forensic evaluation.

NAIDOO, N.; LAZARUS, L.; AJAYI, N. O. \& SATYAPAL, K. S. Antropometría de la tibia del negro adulto: Un estudio sudafricano. Int. J. Morphol., 33(2):600-606, 2015.

RESUMEN: La tibia es el hueso largo y medial de la pierna, con un eje y dos extremos expandidos. Además de ser considerado como posible donante de injerto, se ha confirmado su importancia en el ámbito forense. Este estudio tuvo como objetivo investigar los parámetros morfológicos, morfométricos y antropométricos de la tibia que son de importancia clínica. Se llevó a cabo un examen morfológico y morfométrico de 302 muestras de tibias perteneciente a negros sudafricanos adultos, obtenidas desde el banco osteológico del Departamento de Anatomía Clínica de la Universidad de KwaZulu-Natal. La muestra estuvo constituída por 168 hombres y 134 mujeres, con un rango etario entre 15 y 87 años. El número de forámenes nutricios fueron los siguientes: (a) Únicos (hombres: 98,2\%; mujeres 99,3\%); (b) Doble (hombres: 1,8\%; mujeres: 0,7\%). La relación del foramen nutricio con la línea del sóleo fue: (a) inferomedial (hombres: 0,6\%; mujeres: 1,5\%); (b) inferior y anterior a la mitad inferior del hueso (hombres: 8,2\%; mujeres: $2,2 \%$ ); (c) inferolateral (hombres $=81,8 \%$; mujeres $=88,9 \%)$; (d) infero-lateral, a lo largo del margen interóseo (hombres: $4,1 \%$; mujeres: $3,0 \%$ ); $(\mathrm{e}$ ) supero-medial (hombres: 4,7\%; mujeres: 3,7\%); (f) supero-medial, a lo largo del margen interóseo (hombres: 0,6\%; mujeres: 0\%); (g) supero-lateral (hombres: 0\%; mujeres: 0,7\%). Estadísticamente, se registraron diferencias significativas en los parámetros morfométricos tibiales entre hombres y mujeres. La relación entre el número de forámenes nutricios y la línea del sóleo tuvo significación estadística $(p=0,002)$. La mayor prevalencia de un solo foramen nutricio observada en este estudio, se compara favorablemente con los casos reportados en la literatura analizada. El reconocimiento de la distribución regional de los forámenes nutricios puede evitar lesiones durante los procedimientos de injerto de hueso tibial. Un conocimiento profundo de la anatomía de la tibia también puede aportar datos demográficos necesarios para la investigación forense.

PALABRAS CLAVE: Tibia; Foramen nutricio; Línea del sóleo; Morfometría.

\section{REFERENCES}

Agnihotri, A. K.; Kachhwaha, S.; Jowaheer, V. \& Singh, A. P. Estimating stature from percutaneous length of tibia and ulna in Indo-Mauritian population. Forensic Sci. Int., 187(1-3):109, 2009.

Akhlaghi, M.; Sheikhazadi, A.; Khosravi, N.; Pournia, Y. \& Saberi Anary, S. H. S. The value of the anthropometric parameters of the tibia in the forensic identification of the Iranian population over the age of 20. J. Forensic Leg. Med., 18(6):257-63, 2011.
Antonova, E.; Le, T. K.; Burge, R. \& Mershon, J. Tibia shaft fractures: costly burden of nonunions. B. M. C. Musculoskelet. Disord., 14:42, 2013.

Arora, S.; Goel, N.; Aggarwal, P.; Singh, A.; Sabharwal, A. \& Panda, S. Salvage of proximal tibia fracture treated with locked compression plate. J. Clin. Orthop. Trauma, 3(1):58-61, 2012.

Benninger, B.; Ross, A. \& Delamarter, T. Approaches to proximal 
tibial bone harvest techniques. J. Oral Maxillofac. Res., 3(2):e2, 2012.

Bokariya, P.; Sontakke, B.; Waghmare, J. E.; Tarnekar, A.; Tirpude, B. H. \& Shende, M. R. The anthropometric measurements of tibia. J. Indian Acad. Forensic Med., 34(4):322-3, 2012.

Chitkara, P.; Anne, R.; Lavianlivi, S.; Lehto, S. \& Kolla, S. Imaging review of adolescent tibial tuberosity fractures. Open J. Med. Imaging, 3:90-6, 2013.

Craig, J. G.; Widman, D. \& van Holsbeeck, M. Longitudinal stress fracture: patterns of edema and the importance of the nutrient foramen. Skeletal Radiol., 32(1):22-7, 2003.

Cristofolini, L.; Angeli, E.; Juszczyk, J. M. \& Juszczyk, M. M. Shape and function of the diaphysis of the human tibia. $J$. Biomech.,46(11):1882-92, 2013.

Gandhi, S.; Singla, R. K.; Kullar, J. S.; Agnihotri, G.; Mehta, V.; Suri, R. K. \& Rath, G. Human tibial torsion--morphometric assessment and clinical relevance. Biomed. J., 37(1):10-3, 2014.

Golding, J. S. The mechanical factors which influence bone growth. Eur. J. Clin. Nutr., 48 Suppl. 1:S178-85, 1994.

Gosman, J. H.; Hubbell, Z. R.; Shaw, C. N. \& Ryan, T. M. Development of cortical bone geometry in the human femoral and tibial diaphysis. Anat. Rec. (Hoboken), 296(5):774-87, 2013.

Greenwald, A. S.; Boden, S. D.; Goldberg, V.M.; Khan, Y.; Laurencin, C. T.; Rosier, R. N. \& American Academy of Orthopaedic Surgeons. The Committee on Biological Implants. Bone-graft substitutes: facts, fictions, and applications. J. Bone Joint Surg. Am., 83-A Suppl. 2 Pt. 2:98-103, 2001.

Iscan, M. Y. \& Miller-Shaivitz, P. Discriminant function sexing of the tibia. J. Forensic Sci., 29(4):1087-93, 1984.

Iscan, M. Y.; Yoshino, M. \& Kato, S. Sex determination from the tibia: standards for contemporary Japan. J. Forensic Sci., 39(3):785-92, 1994.

Kirici, Y. \& Ozan, H. Determination of sex from the tibia of adult Turkish cadavers. Kaibogaku Zasshi, 74(5):537-43, 1999.

Kulkarni, N. V. Clinical Anatomy: A problem solving approach. New Dehli, Jaypee Brothers Medical Publishers (P) Ltd., 2012.

Lee, S. H.; Kim, T. H.; Lee, H. H.; Park, J.; Chung, S. H. \& Jeon, D. S. Length measurement of fetal long bone and fetal anomaly detection. Obstet. Gynaecol., 4(5):WMC004236, 2013.

Longia, G. S.; Ajmani, M. L.; Saxena, S. K. \& Thomas, R. J. Study of diaphyseal nutrient foramina in human long bones. Acta Anat. (Basel), 107(4):399-406, 1980.
Moore, K. L.; Daly, A. F. \& Agur, A. M. R. Clinically Oriented Anatomy. Baltimore, Lippincott Williams \& Wilkins, 2010.

Mysorekar, V. R. Diaphysial nutrient foramina in human long bones. J. Anat., 101(Pt. 4):813-22, 1967.

Musa, M.; Joseph, N.; Pamela, M.; Moses, O. \& Gikenye, G. Sexual dimorphism in the morphometric characteristics of the tibial plafond and medial malleolus. Indian J. Basic Appl. Med. Res., 2(7):760-3, 2013.

Newsham-West, R. J.; Lyons, B. \& Milburn, P. D. Regional bone geometry of the tibia in triathletes and stress reactions--an observational study. J. Sci. Med. Sport, 17(2):150-4, 2014.

Parekh, H. P.; Dwidmuthe, S. C.; Patil, S. D. \& Sonar, S. Complex compound fracture of tibia managed with distraction osteogenesis. J. Orthop. Case Rep., 4(3):56-8, 2014.

Pelin, I. C. \& Duyar, I. Estimating stature from tibia length: a comparison of methods. J. Forensic Sci., 48(4):708-12, 2003.

Ruff, C. B. \& Hayes, W. C. Sex differences in age-related remodeling of the femur and tibia. J. Orthop. Res., 6(6):88696, 2005.

Shapiro, F. Bone development and its relation to fracture repair. The role of mesenchymal osteoblasts and surface osteoblasts. Eur. Cell Mater., 15:53-76, 2008.

Slaus, M.; Bedic, Z.; Strinovic, D. \& Petrovecki, V. Sex determination by discriminant function analysis of the tibia for contemporary Croats. Forensic Sci. Int., 226(1-3):302, 2013.

Standring, S. Gray's Anatomy: The Anatomical Basis of Clinical Practice. 40th ed. Barcelona, Churchill Livingstone Elsevier, 2008.

Correspondence to:

Professor KS Satyapal

Department of Clinical Anatomy

School of Laboratory Medicine and Medical Sciences

College of Health Sciences

University of KwaZulu-Natal

Private Bag X54001

Durban

4000

SOUTH AFRICA

Email: satyapalk@ukzn.ac.za

Received:

Accepted: 